\title{
Path Analysis on the Biopsychosocial and Economic Determinants of Quality of Life in Patients with Type II Diabetes Mellitus: Evidence from Surakarta, Central Java
}

\author{
Rahsunji Intan Nurvitasari'1), Didik Gunawan Tamtomo²), Yulia Lanti Retno Dewi²) \\ ${ }^{1)}$ Masters Program in Public Health, Universitas Sebelas Maret \\ 2)Department of Public Health, Faculty of Medicine, Universitas Sebelas Maret
}

\section{ABSTRACT}

Background: Type 2 diabetes mellitus (DM) is a chronic disease that is increasing to an alarming stage in the world. Type 2 diabetes mellitus can have a major impact on the quality of life in patients. The quality of life in patients with type 2 DM is affected by various factors. This study aimed to analyze the biopsychosocial and economic determinants of the quality of life in patients with type $2 \mathrm{DM}$.

Subjects and Method: This was an analytical observational study with a cross-sectional design. This study was conducted in Surakarta from March to May 2020. A sample of 100 patients was selected by purposive sampling. The dependent variable was quality of life. The independent variables were age, blood sugar level, Body Mass Index (BMI), central obesity, education level, smoking habits, stress levels, family social support, physical activity, other diseases, occupation, income, health insurance. This study used a questionnaire to collect the data. This study was analyzed by path analysis using Stata version 13 . Results: The quality of life in patients with type $2 \mathrm{DM}$ increased by family support $(b=0.86$;
95\% $\mathrm{CI}=-0.16$ to $1.87 ; \mathrm{p}=0.098)$, education $(\mathrm{b}=$ $1.47 ; 95 \% \mathrm{CI}=0.47$ to $2.47 ; \mathrm{p}=0.004)$, and occupation $(\mathrm{b}=1.09 ; 95 \% \mathrm{CI}=-0.06$ to $2.23 ; \mathrm{p}=0.062)$. The quality of life in patients with type $2 \mathrm{DM}$ decreased by HbA1c levels $(b=-1.74 ; 95 \% \mathrm{CI}=-$ 2.80 to $-0.69 ; \mathrm{p}=0.001)$ and $\mathrm{BMI}(\mathrm{b}=-1.41 ; 95 \%$ $\mathrm{CI}=-2.49$ to $-0.34 ; \mathrm{p}=0.010)$. Quality of life in patients with type $2 \mathrm{DM}$ was indirectly affected by physical activity and education.

Conclusion: Quality of life in patients with type $2 \mathrm{DM}$ is directly affected by HbA1c levels, BMI, family support, education, and occupation. Quality of life in patients with type $2 \mathrm{DM}$ is indirectly affected by physical activity and education.

Keywords: Quality of life, type 2 diabetes mellitus, biopsychosocial, path analysis.

\section{Correspondence:}

Rahsunji Intan Nurvitasari. Masters Program in Public Health, Universitas Sebelas Maret. Jl. Ir. Sutami 36A, Surakarta 57126, Central Java. Email: intan.nurvitasarI@gmail.com. Mobile: $+6281232599161$

\section{Cite this as:}

Nurvitasari RI, Tamtomo DG, Dewi YLR (2020). Path Analysis on the Biopsychosocial and Economic Determinants of Quality of Life in Patients with Type II Diabetes Mellitus: Evidence from Surakarta, Central Java. J Epidemiol Public Health. 05(03): 281-292. https://doi.org/10.26911/jepublichealth.2020.05.03.03.

(c) (i) (2) Journal of Epidemiology and Public Health is licensed under a Creative Commons Journal of Epidemiology and Public Health is licensed under a Creative
Attribution-Non Commercial-Share Alike 4.0 International License.

\section{BACKGROUND}

Diabetes mellitus (DM) is one of the most common chronic diseases in the world (Jing et al., 2018). The prevalence of DM sufferers in the world is increasing to an alarming stage (Latif et al., 2016). A total of 328 million people suffered from diabetes in 2013. It is estimated to increase to 370 million people in 2030 (Spasić et al., 2014).
Indonesia ranked $6^{\text {th }}$ in the world with 10.3 million people suffering from DM (IDF, 2015). Based on data from the Basic health research in 2018, the prevalence of DM in Indonesia was $2 \%$. This condition is higher than the prevalence in 2013 by $1.5 \%$. A total of 33 provinces in Indonesia had an increase in the prevalence of DM. Central Java was in 12th place with the prevalence of DM by $1.6 \%$ 
in 2013. It increased by $2.1 \%$ in 2018 (Ministry of Health, 2018). Surakarta has quite a lot of DM cases. Based on the data from the Surakarta Health Office, 26,887 people were suffering from diabetes in 2018.

According to Jing et al. (2018), 90\% of diabetes sufferers were patients with type 2 diabetes mellitus. Type 2 DM can cause short-term and long-term effects that affect the health and quality of life of the sufferers. Patients with Type 2 DM have great pressure to treat themselves and have a lower quality of life than healthy people.

The quality of life is affected by various factors. According to John et al. (2019), patients with type $2 \mathrm{DM}$ with $\mathrm{BMI} \geq 25 \mathrm{~kg} / \mathrm{m}^{2}$ or BMI $\leq 25 \mathrm{~kg} / \mathrm{m}^{2}$ had a lower quality of life than patients with normal BMI.

Based on the study, quality of life was related to educational status. The educational status in patients with type $2 \mathrm{DM}$ with elementary school education and illiteracy had a relatively low quality of life than highly educated patients $(\mathrm{p}<0.005)$ (Nyanzi et al., 2014).

Another factor was physical activity. Patients who did more physical exercise had a better quality of life than patients who did little physical activity $(\mathrm{OR}=0.68 ; 95 \% \mathrm{CI}=0.51$ to 0.91) (Jing et al., 2018).

Based on a study conducted by Prajapati et al. (2017), patients with HbA1c by 7$8 \%$ had a better quality of life than patients with $\mathrm{HbA1c}$ by $4-7 \%$ or $>8 \%(\mathrm{p}=0.025)$.

According to a study conducted by Javanbakht et al. (2012), job status had a relationship with the quality of life in patients with type 2 DM. Unemployed patients with type $2 \mathrm{DM}$ had a lower quality of life than patients with type $2 \mathrm{DM}$ patients who worked as civil servants, private employees, and traders (Reba et al, 2018).

Patients' anxiety and concerns about DM were also risk factors for worse quality of life (Donald et al., 2013). Due to depression, patients would smoke, drunk alcohol, and broke adherence to treatment (Lin and Sun, 2010). Social support from family, friends, and the community positively affected patients with type 2 DM (de la Cruz et al., 2019).

Therefore, the researchers were interested in conducting the study on "path analysis on the biopsychosocial and economic determinants of quality of life in patients with type 2 diabetes mellitus" with biological (BMI, HbA1c), psychosocial determinants (education, stress levels, family social support, physical activity), and economic determinants (occupation).

\section{SUBJECTS AND METHOD}

\section{Study Design}

This study was an analytical observational study with a cross-sectional approach. This study was analyzed by path analysis.

\section{Population dan Sample}

The population of this study was all outpatients who were undergoing recurrent control with a diagnosis of type $2 \mathrm{DM}$ in the Community Health Center of the Surakarta Health Office.

\section{Study Variables}

The variables of the study were quality of life in patients with type $2 \mathrm{DM}, \mathrm{BMI}, \mathrm{HbA1c}$, education, stress level, family social support, physical activity, and occupation.

4. Operational Definition of Variables Quality of life was a condition that described the quality of life in patients with type $2 \mathrm{DM}$. The measuring instrument was the Diabetes Quality of Life (DqoL) questionnaire with the version of The Revised Version of DqoL (RV-DqoL). The data scale was continuous. The data were converted into dichotomous data to facilitate the analysis. Code $\mathrm{O}=$ poor quality of life $(\geq 71.75)$; and $1=$ good quality of life $(<71.75)$.

Education was the last formal education taken by patients with type $2 \mathrm{DM}$. This study used a questionnaire. The data scale was 
categorical data. The data were converted into dichotomous data to facilitate the analysis. Code $\mathrm{O}=$ low education $(<$ Senior High School); and $1=$ high education ( $\geq$ Senior High School).

Blood sugar level was the result of checking up blood sugar levels (HbA1c) in the laboratory, in the last 3 months. The measuring instrument was the Spectrophotometer Colorimeter. The data scale was continuous data. The data were converted into dichotomous data to facilitate the analysis. Code $\mathrm{O}=\mathrm{HbA1c}$ level $<6.5 \%$; and $1=\mathrm{HbA1c}$ level $\geq 6.5 \%$.

BMI (Body Mass Index) was an index of body mass based on body weight and height to determine the condition of abnormal fat accumulation in the body. The measuring instrument was stature meters and scales. The data scale was continuous data. The data were converted into dichotomous data to facilitate the analysis. Code $\mathrm{O}=$ normal (BMI $<25 \mathrm{~kg} / \mathrm{m} 2$ ); dan $1=$ obesity (BMI $\geq 25$ $\mathrm{kg} / \mathrm{m} 2)$.

Stress level was a mood disorder in patients with type $2 \mathrm{DM}$, including emotional burden, physician distress, regimen distress, interpersonal distress. The measuring instrument was the Diabetes Distress Scale (DDS) questionnaire. The data scale was continuous data. The data were converted into dichotomous data to facilitate the analysis. Code $\mathrm{O}=$ no distress/mild distress $(<1.17)$; dan $1=$ moderate distress/severe distress $(\geq 1.17)$.

Family social support was the support provided by families to patients with type 2 DM. The measuring instrument was the Hensarling Diabetes Family Support Scale (HDFSS) questionnaire. The data scale was continuous. The data were converted into dichotomous data to facilitate the analysis. Code $0=$ poor $(<2.01)$; and $1=\operatorname{good}(\geq 2.01)$. Physical activity was a physical activity carried out continuously. It was related to the occupation, free time, or travel in the last 7 days. The measuring instrument was the IPAQ-SF questionnaire. The data scale was continuous. The data were converted into dichotomous data to facilitate the analysis. Code $0=$ low physical activity $(\leq 1,500$ METsminutes/week); and 1= high physical activity ( $>1,500$ METs- minutes/week).

Occupation was the main activity carried out by the respondents. The respondents earned income from these activities that were still being carried out during the study. The measuring instrument was a questionnaire. The data were converted into dichotomous data to facilitate the analysis. Code $\mathrm{O}=\mathrm{un}$ employed; and 1= employed.

\section{Study Instruments}

The instrument of the study was a questionnaire that had been tested for validity and reliability. The questionnaire was in the form of a closed questionnaire. Therefore, the respondent chose the answer according to the condition and reality.

\section{Data Analysis}

Univariate analysis aimed to see the frequency distribution and the percentage of the characteristics of the study subjects. Bivariate analysis aimed to determine the relationship between the independent variables and the dependent variable using the Chi-square test. Multivariate analysis used path analysis.

\section{Research Ethic}

The ethical clearance was obtained from the Health Research Ethics Commission of Dr. Moewardi Hospital, Surakarta. Number: 274/II/HREC/2020 which was published on February 17, 2020.

\section{RESULTS}

\section{A. Sample Characteristics}

\section{The Characteristics of the Study Subjects}

The characteristics of the study subjects were in Table 1 and 2. 
Nurvitasari et al./ Biopsychosocial and Economic Determinants of Quality of Life

Table 1. The characteristics of the study subjects (continuous data)

\begin{tabular}{llllll}
\hline Characteristic & n & Mean & SD & Min. & Max. \\
\hline Age (years) & 100 & 61.5 & 8.0 & 45 & 78 \\
Quality of Life (QoL) & 100 & 70.2 & 7.5 & 52.3 & 90.8 \\
Physical activity (METs) & 100 & $2,335.4$ & $1,647.3$ & 240 & 8,484 \\
BMI (kg/m ${ }^{2}$ ) & 100 & 25.9 & 3.6 & 18.1 & 35.2 \\
Abdominal circumference (cm) & 100 & 89.5 & 9.8 & 70 & 134 \\
Stress & 100 & 1.2 & 0.2 & 1 & 2 \\
Family support & 100 & 2 & 0.5 & 1 & 3.2 \\
Length of suffering from DM (years) & 100 & 9.8 & 4.8 & 0.5 & 23 \\
HbA1c (\%) & 100 & 7.9 & 2.1 & 4.5 & 15.2 \\
Income (Rupiah) & 100 & $1,569,100$ & $1,411,653$ & 0 & 6, oOo, OOO \\
\hline
\end{tabular}

Table 2. The characteristics of the study subjects (dichotomous data)

\begin{tabular}{|c|c|c|c|}
\hline Characteristic & Category & $\mathbf{n}$ & $\%$ \\
\hline \multirow[t]{2}{*}{ Quality of Life (QoL) } & Good & 39 & 39 \\
\hline & Poor & 61 & 61 \\
\hline \multirow[t]{2}{*}{ Age (years) } & $<60$ years & 44 & 44 \\
\hline & $\geq 60$ years & 56 & 56 \\
\hline \multirow[t]{2}{*}{ Sex } & Male & 40 & 40 \\
\hline & Female & 60 & 60 \\
\hline \multirow[t]{2}{*}{ Education } & $<$ Senior High School & 64 & 64 \\
\hline & $\geq$ Senior High School & 36 & 36 \\
\hline \multirow[t]{2}{*}{ Occupation } & Unemployed & 70 & 70 \\
\hline & Employed & 30 & 30 \\
\hline \multirow[t]{2}{*}{ Income } & $<$ Minimum Wage & 54 & 54 \\
\hline & $\geq$ Minimum Wage & 46 & 46 \\
\hline \multirow{2}{*}{ Abdominal circumference } & Normal & 20 & 20 \\
\hline & Obesity & 80 & 80 \\
\hline \multirow[t]{2}{*}{ BMI } & Normal & 33 & 33 \\
\hline & Obesity & 67 & 67 \\
\hline \multirow[t]{2}{*}{ Smoking habit } & Non-smoker & 60 & 60 \\
\hline & Smoker & 40 & 40 \\
\hline \multirow[t]{2}{*}{ Stress } & Mild & 37 & 37 \\
\hline & Severe & 63 & 63 \\
\hline \multirow{2}{*}{ Family support } & Poor & 40 & 40 \\
\hline & Good & 60 & 60 \\
\hline \multirow[t]{2}{*}{ Physical activity } & Low & 57 & 57 \\
\hline & High & 43 & 43 \\
\hline \multirow[t]{2}{*}{ HbA1c } & $<6.5 \%$ & 46 & 46 \\
\hline & $\geq 6.5 \%$ & 54 & 54 \\
\hline
\end{tabular}

B. The result of bivariate analysis

Bivariate analysis used the Chi-square test.

The result of the bivariate was in Table 3 .
C. The result of multivariate analysis Path analysis aimed to estimate the magnitude and statistical significance of the hypothesized causal relationships among several variables. 
Nurvitasari et al./ Biopsychosocial and Economic Determinants of Quality of Life

Table 3. Bivariate Analysis

\begin{tabular}{|c|c|c|c|c|c|c|c|c|}
\hline \multirow{3}{*}{ Independent Variable } & \multicolumn{4}{|c|}{ Quality of Life } & \multirow{3}{*}{$\mathbf{O R}$} & \multirow{2}{*}{\multicolumn{2}{|c|}{$95 \%$ CI }} & \multirow{3}{*}{$\mathbf{p}$} \\
\hline & \multicolumn{2}{|c|}{ Poor } & \multicolumn{2}{|c|}{ Good } & & & & \\
\hline & $\mathbf{n}$ & $\%$ & $\mathbf{n}$ & $\%$ & & $\begin{array}{c}\text { Lower } \\
\text { limit }\end{array}$ & $\begin{array}{l}\text { Upper } \\
\text { limit }\end{array}$ & \\
\hline \multicolumn{9}{|l|}{ Education } \\
\hline$<$ Senior High School & 47 & 73.4 & 17 & 26.6 & \multirow{2}{*}{$4 \cdot 34$} & \multirow{2}{*}{1.67} & \multirow{2}{*}{11.39} & \multirow{2}{*}{0.001} \\
\hline $\begin{array}{l}\geq \text { Senior High School } \\
\text { Occupation }\end{array}$ & 14 & 38.9 & 22 & 61.1 & & & & \\
\hline Employed & 46 & 65.7 & 24 & 34.3 & \multirow{3}{*}{1.92} & \multirow{3}{*}{0.73} & \multirow{3}{*}{5.00} & \multirow{3}{*}{0.140} \\
\hline Unemployed & 15 & 50 & 15 & $\begin{array}{c}5+.5 \\
50\end{array}$ & & & & \\
\hline BMI & & & & & & & & \\
\hline Normal & 15 & 45.4 & 18 & 54.6 & \multirow{2}{*}{0.38} & \multirow[b]{2}{*}{0.15} & \multirow{3}{*}{0.98} & \multirow[b]{2}{*}{0.025} \\
\hline Obesity & 125 & 87.41 & 18 & 12.59 & & & & \\
\hline \multicolumn{8}{|l|}{ Stress } & \\
\hline Mild stress & 23 & 62.2 & 14 & 37.8 & \multirow{3}{*}{1.08} & \multirow{3}{*}{0.43} & \multirow{3}{*}{2.72} & \multirow{3}{*}{0.855} \\
\hline Severe stress & 38 & 60.3 & 25 & 39.7 & & & & \\
\hline Family support & & & & & & & & \\
\hline Poor & 30 & 75 & 10 & 25 & \multirow{3}{*}{2.80} & \multirow{3}{*}{1.09} & \multirow{3}{*}{$7 \cdot 56$} & \multirow{3}{*}{0.019} \\
\hline Good & 31 & 51.7 & 29 & 48.3 & & & & \\
\hline Physical activity & & & & & & & & \\
\hline Low & 44 & 77.2 & 13 & 22.8 & \multirow{3}{*}{5.18} & \multirow{3}{*}{1.20} & \multirow{3}{*}{13.60} & \multirow{3}{*}{$<0.001$} \\
\hline High & 17 & 39.5 & 26 & 60.5 & & & & \\
\hline HbA1c & & & & & & & & \\
\hline$<6.5 \%$ & 20 & $43 \cdot 5$ & 26 & 56.5 & 0.24 & 0.09 & 0.62 & 0.001 \\
\hline$\geq 6.5 \%$ & 41 & 75.9 & 13 & 24.1 & & & & \\
\hline
\end{tabular}

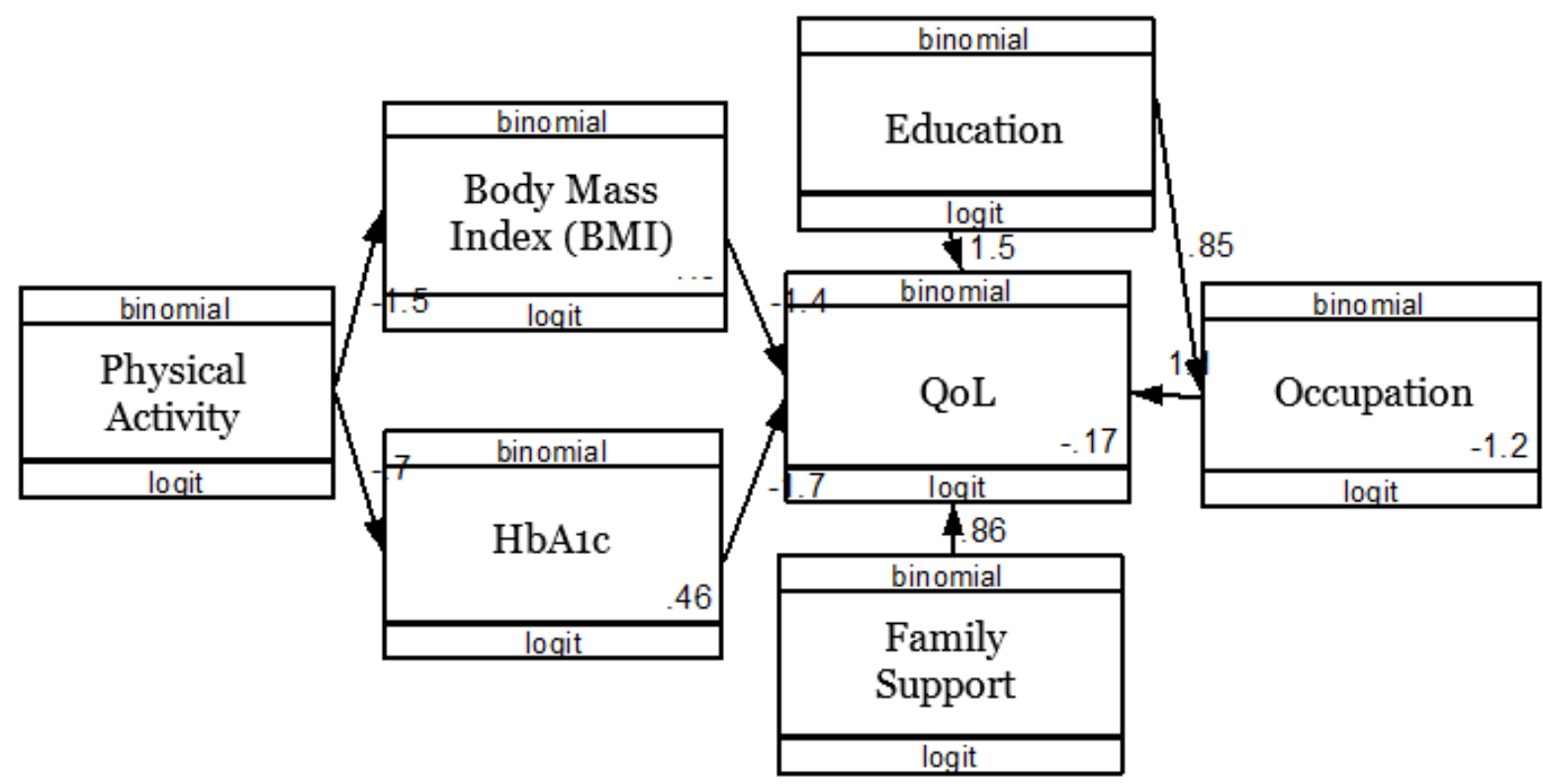

Figure 1. The diagram of the path analysis of the biopsychosocial and economic determinants of quality of life in patients with type II DM 
Nurvitasari et al./ Biopsychosocial and Economic Determinants of Quality of Life

Table 4. Multivariate Analysis

\begin{tabular}{|c|c|c|c|c|c|}
\hline \multirow{2}{*}{$\begin{array}{l}\text { Dependent } \\
\text { Variable }\end{array}$} & \multirow{2}{*}{ Independent Variable } & \multirow{2}{*}{$\mathbf{b}$} & \multicolumn{2}{|l|}{ CI 95\% } & \multirow[b]{2}{*}{$\mathbf{p}$} \\
\hline & & & $\begin{array}{l}\text { Lower } \\
\text { limit }\end{array}$ & $\begin{array}{l}\text { Upper } \\
\text { limit }\end{array}$ & \\
\hline \multicolumn{6}{|l|}{ Direct Effect } \\
\hline Quality of Life (QoL) & $\leftarrow \operatorname{HbA1c}(\geq 6.5 \%)$ & -1.74 & -2.80 & -0.69 & 0.001 \\
\hline & $\leftarrow$ BMI (Obesity) & -1.41 & -2.49 & -0.34 & 0.010 \\
\hline & $\leftarrow$ Family support (Good) & 0.86 & -0.16 & 1.87 & 0.098 \\
\hline & $\leftarrow \begin{array}{l}\text { Education ( } \geq \text { Senior High } \\
\text { School) }\end{array}$ & 1.47 & 0.47 & 2.47 & 0.004 \\
\hline & $\leftarrow$ Occupation (Employed) & 1.09 & -0.06 & 2.23 & 0.062 \\
\hline \multicolumn{6}{|l|}{ Indirect Effect } \\
\hline HbA1c ( $\geq 6.5 \%)$ & $\leftarrow$ Physical activity (High) & -0.70 & -1.50 & 0.10 & 0.089 \\
\hline BMI (Obesity) & $\leftarrow$ Physical activity (High) & -1.48 & -2.37 & -0.59 & 0.001 \\
\hline $\begin{array}{l}\text { Occupation } \\
\text { (Employed) }\end{array}$ & $\leftarrow \begin{array}{l}\text { Pendidikan }(\geq \text { Senior High } \\
\text { School) }\end{array}$ & 0.85 & -0.03 & 1.72 & 0.059 \\
\hline $\begin{array}{l}\mathrm{N} \text { observation }=100 \\
\mathrm{AIC}=492.59 \\
\mathrm{BIC}=523.85\end{array}$ & & & & & \\
\hline
\end{tabular}

1. The effect of HbArc level on the Quality of Life (QoL) in Patients with Type II Diabetes Mellitus

There was a direct and negative effect of HbA1c levels on quality of life (QoL) in patients with Type 2 DM. Patients with Type 2 DM who had an HbA1c level $\geq 6.5$ had logodd of having a good quality of life 1.74 units lower than those with HbA1c level $<6.5$ (b=$1.74 ; 95 \% \mathrm{CI}=-2.80$ to $-0.69 ; \mathrm{p}=0.001$ ).

2. The effect of BMI on the Quality of Life (QoL) in Patients with Type II Diabetes Mellitus

There was a direct and negative effect of BMI on quality of life (QoL) in patients with Type 2 DM, but it was statistically significant. Patients with type 2 DM who were obese had logodd of having a good quality of life 1.41 units lower than patients who were not obese ( $b=-1.41 ; 95 \% \mathrm{CI}=-2.49$ to $-0.34 ; \mathrm{p}=0.010$ ).

3. The effect of family support on the Quality of Life (QoL) in Patients with Type II Diabetes Mellitus

There was a direct and positive effect of family support on the quality of life (QoL) in patients with Type 2 DM. Statistically, it was marginally significant $(\mathrm{p}<0.10)$. Patients with Type 2 DM who had good family support had logodd of having a good quality of life 0.86 units higher than patients who had poor family support $(b=0.86 ; 95 \% \mathrm{CI}=-0.16$ to $1.87 ; \mathrm{p}=0.098$ ).

4. The effect of education on the Quality of Life (QoL) in Patients with Type II Diabetes Mellitus

There was a direct and positive effect of education on the quality of life (QoL) in patients with Type $2 \mathrm{DM}$, but it was statistically significant. Patients with type $2 \mathrm{DM}$ who had $\geq$ Senior High School education had logodd of having a good quality of life $\mathbf{1 . 4 7}$ units higher than patients who had $<$ Senior High School education $(b=1.47 ; 95 \% \mathrm{CI}=0.47$ to $2.47 ; \mathrm{p}=0.004$ ).

5. The effect of occupation on the Quality of Life (QoL) in Patients with Type II Diabetes Mellitus

There was a direct and positive effect of occupation on the quality of life (QoL) in patients with Type 2 DM. Statistically, it was margin- 
ally significant $(\mathrm{p}<0.10)$. Patients with Type 2 diabetes who worked had logodd of having a good quality of life 1.09 units higher than patients who did not work $(b=1.09$; $95 \% \mathrm{CI}=-$ 0.06 to $2.23 ; \mathrm{p}=0.062$ ).

\section{The effect of HbA1c on the Quality of Life (QoL) in Patients with Type II Diabetes Mellitus through physical activity}

Patients with Type 2 DM who had HbA1c levels $\geq 6.5$ had logodd of having a good quality of life through physical activity $(b=-$ $0.70 ; 95 \% \mathrm{CI}=-1.50$ to $0.10 ; \mathrm{p}=0.089$ ).

7. The effect of BMI on the Quality of Life (QoL) in Patients with Type II Diabetes Mellitus through physical activity

Patients with Type 2 DM who had obesity had logodd of having a good quality of life through physical activity $(\mathrm{b}=-1.48 ; 95 \% \mathrm{CI}=-$ 2.37 to $-0.59 ; \mathrm{p}=0.001$ ).

8. The effect of occupation on the Quality of Life (QoL) in Patients with Type II Diabetes Mellitus through education

Patients with Type 2 DM who worked had logodd of having a good quality of life through education $(\mathrm{b}=0.85 ; 95 \% \mathrm{CI}=-0.03$ to 1.72; $\mathrm{p}=0.059$ ).

\section{DISCUSSION}

1. The effect of HbArc level on the Quality of Life (QoL) in Patients with Type II Diabetes Mellitus

The result of this study indicated that there was a direct effect of HbA1c levels on the quality of life in patients with Type $2 \mathrm{DM}$ and statistically significant $(b=-1.74 ; 95 \% \mathrm{CI}=-$ 2.80 to $-0.69 ; \mathrm{p}=0.001)$. Patients with Type 2 DM who had HbA1c levels $\geq 6.5$ had logodds of having a good quality of life 1.74 units lower than patients who had HbA1c levels $<6.5$.

Based on a study conducted by Genga et al. (2014), poor quality of life was found in patients with HbA1c $\geq 7.5$. The ability of patients with Type $2 \mathrm{DM}$ in diabetes management could be determined by examining HbA1c levels, such as controlling blood sugar and knowing the possibility of complications. HbA1c levels showed better long-term blood sugar control than short-term blood sugar levels or urine in days or hours (Sacks et al., 2011).

Uncontrolled DM and poor glycemic control could cause hyperglycemia symptoms that affected the quality of life (Spasic et al., 2014). Through the patient's ability to implement glycemic control, the likelihood of causing comorbidity was very small. This behavior affected the patient's quality of life so that the patient could enjoy life (Wang et al., 2017).

Poor glycemic control was likely caused by the patient's lack of knowledge about selfcare resulting in inadequate self-management. In addition, it caused complications such as retinopathy, nephropathy, neuropathy which significantly reduced the quality of life (Genga et al., 2014; Latif, 2016).

\section{The effect of BMI on the Quality of Life (QoL) in Patients with Type II Diabetes Mellitus}

The result of this study indicated that there was a direct effect between BMI and the quality of life in patients with Type $2 \mathrm{DM}$ and statistically significant $(\mathrm{b}=-1.41 ; 95 \% \mathrm{CI}=-$ 2.49 to $-0.34 ; \mathrm{p}=0.010)$. Patients with type 2 DM who were obese had logodd of having a good quality of life 1.41 units lower than patients who were not obese.

Eckert (2012) stated that type $2 \mathrm{DM}$ had a clinically significant effect on the quality of life of individuals who were overweight or obese. In addition, weight gain could be an important predictor of quality of life among people with type $2 \mathrm{DM}$. Quality of life got worse as BMI increase. It is in line with this study that patients with obesity of grade II (BMI> 35) had the lowest quality of life than 
patients with a body weight by 25-29.9 and patients with obesity of grade I (BMI 30-35) $(\mathrm{p}=0.01)$.

According to a study conducted by John et al. (2019), BMI had a significant correlation with quality of life $(\mathrm{p}<0.005)$. Patients

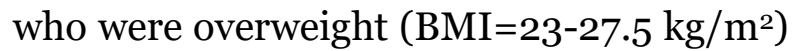
or had body weight (BMI $\leq 18.5 \mathrm{~kg} / \mathrm{m}^{2}$ ) had lower mean scores of quality of life than patients with Type $2 \mathrm{DM}$ with normal weight. There was an increased risk of complications associated with an increase in BMI. It decreased physical health. Besides, it affected the quality of life in patients.

\section{The effect of family support on the Quality of Life (QoL) in Patients with Type II Diabetes Mellitus}

The result of this study indicated that there was a direct effect of family support on the quality of life in patients with Type $2 \mathrm{DM}$. Statistically, it was marginally significant. Patients with Type 2 DM who had good family support had logodd of having a good quality of life 0.86 units higher than patients who had poor family support.

Based on a study conducted by Komaratat et al. (2020), social support was overall significantly and positively related to the quality of life in patients with Type $2 \mathrm{DM}(\mathrm{r}=$ 0.299; $p=0.002)$. Social support consisted of information support, emotional support, appraisal support, moral support, and instrumental support including money, materials, labor, and services. Patients with Type 2 DM who were still receiving emotional warmth and moral support would do more self-care, thus improving the quality of life. The warmth and love of the family had a positive effect on health and behavior in diabetic patients leading to a better quality of life.

Counseling from important people such as family members would strengthen a sense of respect and care, thus increasing the desire of the patients to adhere to treatment and develop self-confidence that comes from a better quality of life. Family awareness in providing support could cause patients to adhere to treatment. Therefore, it did not cause further complications. Families could provide support in the form of warning or compliment. Families could provide information about the recommended food and make food modifications so that patients were not saturated with the diet carried out (Wahyudi et al., 2020).

\section{The effect of education on the Quality of Life (QoL) in Patients with Type II Diabetes Mellitus}

The result of this study indicated that there was a direct effect of education on the quality of life in patients with Type 2 DM and statistically significant. Patients with type 2 DM who had $\geq$ Senior High School education had logodd of having a good quality of life 1.47 units higher than patients who had $<$ Senior High School education.

Educational status was the main sociodemographic variable related to the quality of life. The mean score of quality of life was comparatively lower in patients with Type 2 DM who had basic education than patients with Type 2 DM who had high education (John et al., 2019). This condition occurred because low educational attainment was likely to limit information and resources related to healthy behavior and environmental exposure (Latif et al., 2016).

According to Nyanzi et al. (2014) in the Ugandan perspective, quality of life was significant for education $(\mathrm{p}<0.05)$. The good quality of life in patients with Type $2 \mathrm{DM}$ who had higher education occurred because patients could easily read and understand the effects of diabetes on their health. Therefore, they were more likely to adhere to the recommended treatment. In addition, education was an important factor in understanding self-care management for patients with Type 2 DM, glycemic control, and self-esteem perceptions. 


\section{The effect of occupation on the Quality of Life (QoL) in Patients with Type II DM}

The result of this study indicated that there was a direct effect of occupation on the quality of life in patients with Type 2 DM. Statistically, this was marginally significant. Patients with Type 2 DM who worked had logodd of having a good quality of life 1.09 units higher than patients who did not work.

The quality of life in patients who worked was significantly higher than the housewives and unemployed patients ( $p$ $<0.05$ ) (Abedini et al., 2020). For housewives in Indonesia who had the responsibility of taking care of family members and household chores, having Type 2 DM was an additional burden in carrying out these tasks (Arifin et al., 2019).

According to Fauziyah et al. (2020), work could improve a person's ability to carry out her/his role. Patients with Type 2 diabetes in Surakarta who were generally elderly and still working had physical and mental abilities and still could work. They were still working due to economic pressure or they had to support their family, children, and grandchildren who were still living together. In addition, work was a form of self-actualization affecting the level of quality of life. Bahadlr and Ekici (2020) stated that activities at work could increase mood so that it could improve the quality of life in patients, especially for those who suffered from chronic diseases such as diabetes.

\section{The effect of HbA1c on the Quality of Life (QoL) in Patients with Type II DM through physical activity}

The result of this study indicated that HbA1c levels had an indirect effect on the quality of life through physical activity. Statistically, it was marginally significant.

A study by Fajriyah et al. (2020) showed the final result of a decrease in HbA1c and an increase in the quality of life in patients with Type 2 DM. Patients who routinely do physical activities such as aerobics at least 3 times a week with a duration of 30-40 minutes per session in 4 weeks for minimum and 25 weeks for maximum had a good quality of life as well as decreased HbA1c. HbA1c levels decreased significantly after aerobic physical activity ( $\mathrm{p}<0.05)$.

Physical activity increased insulin resistance so that insulin became more effective at transporting glucose. Physical activity burned calories in muscles such as glucagon. In addition, to replace the calories burned, the glucose was removed from the blood, thus reducing the sugar in circulation. Physical activity also helped people to lose and maintain body weight to avoid obesity because obesity was one of the causes of Type 2 DM (Gita et al., 2020).

Patients with Type 2 DM needed to do moderate physical activity for 150 minutes per week (6o minutes per week in 5 days) or 60 minutes per week (20 minutes in 3 days) of vigorous physical activity. Doing exercise of more than 150 minutes per week was associated with a higher reduction in $\mathrm{HbA1c}$ than doing exercise by $\leq 150$ per week (Tomas et al., 2019).

Regular physical activity improved blood glucose control, thus preventing or delaying Type 2 DM. It might be more effective in reducing insulin resistance. It also affected the quality of life in patients in a positive way (Çolak et al., 2016).

\section{The effect of BMI on the Quality of Life (QoL) in Patients with Type II DM through physical activity}

The result of this study indicated that Body Mass Index (BMI) had an indirect effect on the quality of life through physical activity and it was statistically significant.

According to a study conducted by Eckert (2012), there was a correlation between BMI and physical activity $(\mathrm{p}=0.05)$. Obese patients who actively engaged in 
Nurvitasari et al./ Biopsychosocial and Economic Determinants of Quality of Life

physical activity had a higher quality of life than obese patients who did not actively engage in physical activity. Patients who spent $<1000$ kcal per week on physical activity had a lower quality of life scores. Physical activity could reduce the log odds of having additional chronic conditions.

Physical activity was a major factor to reduce excess body weight and stabilize a healthy weight level. Besides, it was a catalyst for other bodily processes. Physical activity reduced direct complication factors, supported glycemic control, and improved quality of life (Eckert, 2012).

\section{The effect of occupation on the Quality of Life (QoL) in Patients with Type II DM through education}

The result of this study indicated that occupation had an indirect effect on the quality of life through education and it was statistically significant.

According to Budiarti et al. (2017), someone with higher education would have the opportunity to get a job. As a result, the income would be better. Education had an important role in reducing poverty since education affected income positively. Income would increase if the quality of human life also increased.

Prasetyaningsih et al. (2016) said that someone who worked in the informal sector did not have a fixed income which was expected to meet their needs. This is related to low education. Low education affected low income. Low income caused poverty thus resulting in low health conditions and low quality of life.

\section{AUTHOR CONTRIBUTION}

Rahsunji Intan Nurvitasari was the main researcher who collected the data, formulated the data, designed the study, conducted the questionnaire reliability tests, and analyzed the data. Didik Gunawan Tamtomo suggested the discussion and writing techniques. Yulia
Lanti Retno Dewi examined the data, provided input on the study discussion and writing technique.

\section{CONFLICT OF INTEREST}

This study did not have any conflict of interest.

\section{FUNDING AND SPONSORSHIP}

This study used a personal fund.

\section{ACKNOWLEDGEMENT}

The researcher expressed her gratitude to the Head of the Surakarta Community Health Center for permitting to conduct this study. The researcher would like to thank all patients with Type 2 DM who have been willing and cooperative to become the study subjects.

\section{REFERENCE}

Abedini MR, Bijari B, Miri Z, Shakhs FE, Abbasi A (2020). The quality of life of the patients with diabetes type 2 using EQ-5D-5 L in Birjand. Health and Quality of Life Outcomes, 18(1):1-9. https://doi.org/10.1186/s12955-0201277-8.

Arifin B, Idrus, LR, van Asselt ADI, Purba FD, Perwitasari DA, Thobari JA, Cao Q, et al. (2019). Health-related quality of life in Indonesian type 2 diabetes mellitus outpatients measured with the Bahasa version of EQ-5D. Quality of Life Research, 28(5): 1179-1190. https://doi.org/10.1007/s11136-019-02105-Z

Bahadlr AZ, Ekici G (2020). Person-centred, occupation-based intervention program supported with problem-solving therapy for type 2 diabetes: A randomized controlled trial. Health and Quality of Life Outcomes, 18(1): 265. https://doi.org/10.1186/s12955-020-01521-X.

Budiarti E, Tamtomo DG, Adriani RB (2017). Path analysis on the biopsychosocial 
Nurvitasari et al./ Biopsychosocial and Economic Determinants of Quality of Life

determinants of type 2 diabetes mellitus and depression at Dr. Moewardi Hospital, Surakarta. J Epidemiol Public Health. 03(01): 1-14. https://doi.org/10.26911/jepublichealth.2018.03.01.01. Çolak TK, Acar G, Dereli EE, Özgül B, Demirbüken İ, Alkaç Ç, Polat MG (2016). Association between the physical activity level and the quality of life of patients with type 2 diabetes mellitus. $\mathrm{J}$ Physic Ther Sci. 28(1): 142-147. https://doi.org/10.1589/jpts.28.142.

de la Cruz JPS, Morales DLG, GonzálezCastro TB, Tovilla-Zárate C A, JuárezRojop IE, López-Narváez L, Diaz YH, et al. (2019). Quality of life of Latin-American individuals with type 2 diabetes mellitus: A systematic review. Primary Care Diabetes. 14(4): 317-334. https://doi.org/10.1016/j.pcd.2019.09.003.

Donald M, Dower J, Coll JR, Baker P, Mukandi B, Doi SAR (2013). Mental health issues decrease diabetes-specific quality of life independent of glycaemic control and complications: Findings from Australia's living with diabetes cohort study. Health and Quality of Life Outcomes, 11(1): 170. https://doi.org/10.1186/1477-7525-11-170.

Eckert K (2012). Impact of physical activity and bodyweight on health-related quality of life in people with type 2 diabetes. Diabetes, Metabolic Syndrome and Obesity: Targets and Therapy, 5: 303-311. https://doi.org/10.2147/dmso.s34835.

Fajriyah N, Sudiana IK, Wahyuni ED (2020). The effects from physical exercise on the blood glucose levels, HbA1c and quality of life of type 2 diabetes mellitus patients: A systematic review. Jurnal Ners, 15(2): 486-496. https://doi.org/10.20473/jn.v15i2(si).20517.

Fauziyah AN, Soemanto R, Adriani RB (2020). Contextual effect of integrated health post, socioeconomic and physical and mental health determinants on the quality of life among elderly in Klaten, Central Java. J Epidemiol Public Health. 5(1): 15-25. https://doi.org/10.26911/jepublichealth.2020.05.01.0.

Genga E, Otieno CF, Ogola EN, Maritim MC (2014). Assessment of the perceived quality of life of non-insulin dependent diabetic patients attending the diabetes clinic in Kenyatta National Hospital. Diabetes Res Clin Prac. 103(1): S36. doi:10.1016/s0168-8227(14)70121-4.

Gita APA, Qadrijati I, Murti B (2020). Multilevel analysis: Villages do not have ecological effect on the risk of diabetes mellitus type 2 in Surakarta, Central Java. J Epidemiol Public Health. 5(1): 106-118. https://doi.org/10.26911/jepublichealth.2020.05.01.11.

IDF (2015). IDF Diabetes Atlas Seventh Edition 2015. Brussels: IDF.

Javanbakht M, Abolhasani F, Mashayekhi A, Baradaran HR, Jahangirinoudeh Y (2012). Health Related Quality of Life in Patients with Type 2 Diabetes Mellitus in Iran: A National Survey. PLoS ONE, 7(8):1-9. https://doi.org/10.1371/journal.pone.0044526.

Jing X, Chen J, Dong Y, Han D, Zhao H, Wang X, Gao F, et al. (2018). Related factors of quality of life of type 2 diabetes patients: A systematic review and meta-analysis. Health and Quality of Life Outcomes, 16(1): 1-14. https://doi.org/10.1186/s12955-018-1021-9

John R, Pise S, Chaudhari L, Deshpande P (2019). Evaluation of quality of life in type 2 diabetes mellitus patients using quality of life instrument for indian diabetic patients: A cross-sectional study. Journal of Mid-Life Health, 10(2): 81-88. https://doi.org/10.4103/jmh.JMH_32_18. 
Nurvitasari et al./ Biopsychosocial and Economic Determinants of Quality of Life

Kemenkes (2018). Hasil Riset Kesehatan Dasar Republik Indonesia Tahun 2018. Jakarta: Badan Peneltian dan Pengembangan Republik Indonesia.

Komaratat C, Auemaneekul N, Kittipichai W (2020). Quality of life for type II diabetes mellitus patients in a suburban tertiary hospital in Thailand. J Health Res. o(o):1-12. https://doi.org/10.1108/jhr-05-2019-0100.

Latif FIAE, Wahid HAAE, Mohamed AA, Farg HK (2016). Quality of life of type 2 diabetic patients in relation to gender and socio-economic status in Egypt. Int J Sci \& Scient Res, 2(4): 152-160. https://doi.org/10.25141/2471-67822016-4.0152

Lin Y, Sun Z (2010). Current views on type 2 diabetes. J Endocrinol. 204(1): 1-11. https://doi.org/10.1677/JOE-09-0260

Nyanzi R, Wamala R, Atuhaire LK (2014). Diabetes and quality of life: A Ugandan perspective. J Diabetes Res, 2014:1-9. https://doi.org/10.1155/2014/402012

Prajapati VB, Blake R, Acharya LD, Seshadri

S. (2017). Assessment of quality of life in type II diabetic patients using the modified diabetes quality of life (MDQOL)-17 questionnaire. Brazilian Journal of Pharmaceutical Sciences, 53(4): 1-9. https://doi.org/10.1590/s2175-97902017000417144.

Prasetyaningsih RH, Indarto D, Akhyar M (2016). Association of determinant factors on bio-psychosocial with quality of life in elderly. $\mathrm{J}$ Epidemiol Public Health. 01(02): 108-117. https://doi.org/10.26911/jepublichealth.2016.01.02.04 .

Reba K, Argaw Z, Walle B, Gutema H (2018).
Health-related quality of life of patients with diagnosed type 2 diabetes in Felege Hiwot Referral Hospital, North West Ethiopia: A cross-sectional study. BMC Research Notes, 11(1): 544. https://doi.org/10.1186/s13104-018-3625-x Sacks DB, Arnold M, Bakris GL, Bruns DE, Horvath AR, Kirkman MS, Lernmark A, et al. (2011). Guidelines and recommendations for laboratory analysis in the diagnosis and management of diabetes mellitus. Diabetes Care, 34(6): 1419-1423. https://doi.org/10.2337/dc11-9998.

Spasić A, Radovanović RV, Dordević AC, Stefanović N, Cvetković T (2014). Quality of life in type 2 diabetic patients. Acta Facultatis Medicae Naissensis, 31(3): 193-200. https://doi.org/10.2478/afmnai-2014-0024.

Tomas CP, Leite N, Raimundo A (2019). Effects of physical exercise on the quality of life of type 2 diabetes patients. In Quality of Life. https://doi.org/10.5772/intechopen.87110.

Wahyudi CT, Jadmiko AW, Ritanti R (2020). Family support on the adherence to nutrition intake among adults with primary hypertension in Kalanganyar, Lebak, Banten, Indonesia. J Epidemiol Public Health. 5(2): 132-140. https://doi.org/10.26911/jepublichealth.2020. 05.02.01.

Wang HF, Chen YC, Yang FH, Juan CW (2017). Relationship between type 2 diabetes self-efficacy and quality of life: Analysis under varying glycated hemoglobin conditions. Fam Med Med Sci Res, 6(2):1-11. https://doi.org/10.4172/2327-4972.1000218. 